\title{
Penerapan Media Gambar untuk Meningkatkan Hasil Belajar IPS Materi Tokoh dalam Proklamasi Kemerdekaan
}

\author{
Kontan Ginting \\ SD Negeri 101768 Percut Sei Tuan, Deli Serdang, Indonesia \\ Diterima Pebruari 2017; Disetujui April 2017; Dipublikasikan Juni 2017
}

\begin{abstract}
Abstrak
Penelitian ini bertujuan untuk mengetahui penggunaan media gambar dalam meningkatkan hasil belajar siswa, selain itu untuk mengetahui hasil belajar siswa pada mata pelajaran IPS materi Tokoh Dalam Proklamasi Kemerdekaan di Kelas V SD Negeri 101768 pada tahun pelajaran 2015/2016. Subjek penelitian siswa terdiri dari 14 siswa laki-laki dan 11 siswa perempuan. Data yang dikumpulkan melalui wawancara, catatan lapangan dan dokumentasi. Teknik pengumpulan data menggunakan Tes dan Observasi serta teknik analisis data berupa Reduksi Data, Paparan Data, dan Penyimpulan Data. Hasil penelitian menunjukkan bahwa penggunaan media gambar pada pembelajaran IPS materi tokoh dalam proklamasi kemerdekaan dapat meningkatkan hasil belajar siswa. Peningkatan ini ditunjukkan dengan adanya perubahan, sebelumnya memiliki nilai rata-rata 51,2 dengan ketuntasan klasikal 20\%. Setelah menerapkan pendekatan pembelajaran dengan menggunakan media gambar diperoleh nilai rata-rata tes hasil belajar siswa 67,6 dengan ketuntasan klasikal sebesar 56\%. Pada siklus II di peroleh nilai rata-rata 81,2 dengan ketuntasan klasikal 84\%. Dapat disimpulkan bahwa penerapan media gambar dapat meningkatkan hasil belajar siswa pada mata pelajaran IPS Kelas V SD Negeri 101768 pada tahun ajaran 2015/2016. Dan juga dari hasil penelitian ini cukup memberikan motivasi kepada siswa, dibuktikan dengan hasil belajar dan semangat belajar siswa yang meningkat dan bertambah baik.

Kata Kunci : Hasil Belajar, Penerapan Media Gambar
\end{abstract}

\begin{abstract}
This study aims to determine the use of image media in improving student learning outcomes, in addition to knowing the results of student learning subjects in social studies subjects IPS In Proclamation of Independence in Class V SD Negeri 101768 in the academic year 2015/2016. The subjects of the student study consisted of 14 male students and 11 female students. Data collected through interviews, field notes and documentation. Techniques of collecting data using Tests and Observations and data analysis techniques such as Data Reduction, Data Exposure, and Data Conclusion. The results showed that the use of image media on IPS learning material of the characters in the proclamation of independence can improve student learning outcomes. This increase is indicated by the changes, previously had an average value of 51.2 with $20 \%$ classical completeness. After applying the learning approach using the image media obtained the average score of student learning result test 67.6 with $56 \%$ classical completeness. In cycle II, the average score 81,2 with $84 \%$ classical completeness. It can be concluded that the application of the image media can improve student learning outcomes in the subjects Social Science Class V SD Negeri 101768 in the academic year 2015/2016. And also from the results of this study is enough to provide motivation to students, evidenced by the learning outcomes and spirit of student learning is increased and improved.
\end{abstract}

Keywords: Learning Outcomes, Implementation of Image Media

How to Cite: Ginting, K., (2017), Penerapan Media Gambar Untuk Meningkatkan Hasil Belajar IPS, Anthropos: Jurnal Antropologi Sosial dan Budaya, 3 (1): 25-31

\begin{tabular}{lr}
\hline${ }^{*}$ Corresponding author: & p-ISSN 2460-4585 \\
E-mail: kontanginting@gmail.com & e-ISSN 2460-4593
\end{tabular}




\section{PENDAHULUAN}

Peningkatan hasil belajar siswa merupakan hasil yang di inginkan oleh semua pihak, baik itu dari pihak sekolah seperti kepala sekolah, guru para staf disekolah dan para siswa. Dari pihak keluarga yaitu orang tua dan kerabat. Peningkatan hasil belajar ini tidaklah mungkin dapat berhasil apabila tidak dibarengi dengan usaha yang sungguh-sunggu dalam belajar. Tentu saja dalam usaha yang dilakukan banyak jalan alternative yang bisa dilakukan, di antara nya menghafal atau memahami isi materi di rumah sebelum di pelajari di sekolah, mencari sumber informasi lain yang menyangkut dalam materi pembelajaran, rajin membahas soal-soal, ikut dalam bimbingan belajar dan lain-lain. Apabila hal tersebut salah satu saja dilakukan bisa membantu para siswa dalam mencapai tingkatan hasil belajar yang baik.

Pada hakikatnya individu yang belajar akan mengalami perubahan prilaku berupa pengetahuan, sikap dan keterampilan. Selanjutnya hasil belajar merupakan hasil dari suatu interaksi tindak belajar dan tindak mengajar. Biasanya hasil belajar di dapat dari penilaian yang tidak dapat dipisahkan dari keseluruhan penyelenggara pendidikan. Asumsi dasarnya ialah proses pengajaran yang optimal yang memungkinkan hasil belajar yang optimal pula. Makin besar usaha untuk menciptakan kondisi proses pengajaran, makin tinggi pula hasil atau produk dari pengajaran itu.

Namun berdasarkan hasil observasi yang didapat yang sering terdengar dan dilihat dilapangan masih banyak suatu ketidak pencapaian yang terjadi dalam proses pembelajaran. Ketidak pencapaian ini terjadi karena dalam setiap materi yang di ajarkan sudah ada suatu indikator pencapaian dan tujuan pembelajaran yang akan di capai. Namun pada saat selesai pembelajaran berlangsung apa yang ingin dicapai oleh guru terhadap siswa tidak terpenuhi, ini dilihat dari hasil evaluasi atau hasil latihan-latihan yang diberikan. Para siswa gagal untuk mencapai nilai Kriteria Ketuntasan Minimal (KKM) yang telah ditetapkan berdasarkan permata pelajaran yang ada.
Dalam mata pelajaran IPS nilai KKM yang telah ditentukan oleh sekolah tahun 2015/2016 adalah 70, namun setelah melihat pengamatan langsung hasil latihan siswa tidak sampai mencapai 70 hanya di bawah rata-rata yaitu 60 . Adapun yang mencapai atau lebih dari nilai 70 hanya beberapa siswa saja. Hal ini terjadi akibat beberapa faktor yang mempengaruhi, di antaranya strategi, metode pembelajaran yang kurang diterapkan, variasi pembelajaran yang tidak ada, dan tidak ada media pembelajaran yang mendukung, sehingga banyak para siswa yang tidak memfokuskan perhatian kepada guru serta materi yang di ajarkan.

Pada mata pelajaran IPS materi tokoh dalam proklamasi kemerdekaan merupakan materi yang membahas tentang para tokohtokoh yang berperan dalam mempersiapkan detik-detik pembacaan proklamasi kemerdekaan Indonesia pada saat ini. Dalam materi ini banyak tokoh-tokoh yang berperan di dalam nya. Namun dalam hal ini, apabila materi di ajarkan kepada para siswa tanpa menggunakan strategi, metode, variasi belajar dan media yang mendukung maka tujuan dari pembelajaran tidak akan tercapai. Sehingga hal tersebut untuk mengarahkan kepada memberikan pengetahuan agar tercapainya peningkatan hasil belajar siswa harus di lakukan pendekatan yang digunakan dalam memberikan pengetahuan yang efisien salah satu di antaranya adalah dengan menggunakan media-media pembelajaran yang bervariasi. Karena salah satu sumber belajar yang dapat menyalurkan pesan pembantu menyelesaikan masalah-masalah yang selalu di hadapi dalam proses belajar berlangsung adalah dengan menggunakan media di antaranya adalah media gambar.

Media pembelajaran adalah suatu yang dapat membawa informasi dan pengetahuan dalam intelektual yang berlangsung antara pendidik dan peserta didik dimana media pembelajaran ini secara fisik digunakan untuk menyampaikan isi materi pengajaran, yang terdiri dari buku, tape-recorder, kaset, film, slide, foto/gambar, grafik, televisi dan komputer. 
Jadi dapat di simpulkan bahwa media adalah segala sesuatu yang dapat digunakan untuk menyalurkan pesan dari pengirim ke penerima sehingga dapat merangsang pikiran, perasaan, perhatian, minat serta perhatian siswa sedemikian rupa sehingga proses belajar terjadi. Dalam proses belajar mengajar kehadiran media mempunyai arti yang cukup penting karena di dalam kegiatan tersebut ketidak jelasan bahan yang disampaikan dapat membantu dengan menghadirkan media sebagai perantara. Kerumitan bahan yang akan disampaikan kepada anak didik dapat disederhanakan dengan bantuan media.

Ada banyak jenis media, salah satu nya adalah media gambar. Media gambar merupakan alat visual yang penting dan mudah di dapat secara media tersebut membuat seseorang dapat mengangkat idea tau informasi yang terkandung di dalamnya dengan jelas, lebih jelas dari pada diungkapkan dengan katakata yang ditulis maupun yang diucapkan.

Media gambar atau foto merupakan reproduksi bentuk asli dalam dua dimensi. Gambar atau foto merupakan alat visual yang efektif karena dapat divisualisasikan sesuatu yang akan dijelaskan dengan lebih konkrit dan realistis. Informasi yang disampaikan dapat dimengerti dengan mudah karena hasil yang diragakan lebih mendekati kenyataan foto yang diperhatikan kepada anak-anak, dan hasil yang diterima oleh anak-anak akan sama. Beberapa alasan penggunaan gambar atau foto sebagai pengajaran sebagai berikut: 1) Bersifat konkret, para siswa akan dapat melihat dengan jelas suatu yang sedang dibicarakan atau didiskusikan. 2) Dapat mengatasi batas ruang dan ruang. 3) Dapat mengatasi kekurangan daya mampu panca indera manusia. 4) Dapat digunakan untuk menjelaskan suatu masalah. 5) Mudah di dapat dan mudah biayanya. 6) Mudah digunakan baik untuk perorangan maupun untuk berkelompok.

Kegunaan dari media gambar ini adalah dapat membuat siswa mengetahui tentang bagaimana rupa, gambar, bentuk wajah, ciri-ciri dari tokoh serta dapat membedakan antara tokoh yang satu dan tokoh yang lain serta dapat mengetahui peran dari masing-masing tokoh.
Diketahui bahwa kebanyakan para siswa hanya mengetahui gambar, bentuk wajah dan ciri-ciri tokoh 1 atau 2 saja, itu pun melalui TV, spanduk-spanduk, gambar-gambar yang ada di jalan atau pun dari buku-buku yang ada. Siswa tidak mengetahui bahwa masih banyak tokoh lain yang memberikan peranan penting dalam menyambut detik-detik proklamasi kemerdekaan.

Menurut Sudjana dan Rivai dalam Arsyad menemukan bahwa manfaat media pengajaran dalam proses belajar mengajar siswa adalah: 1) Pengajaran akan lebih menarik perhatian siswa sehingga dapat menumbuhkan minat belajar. 2) Bahan pengajaran akan lebih jelas maknanya sehingga dapat lebih dipahami oleh siswa dan memungkinkannya menguasai dan mencapai tujuan pengajaran. 3) Metode mengajar akan lebih bervariasi, tidak semata-mata berkomunikasi verbal melalui penuturan katakata oleh guru, sehingga siswa tidak bosan dan guru tidak kehabisan tenaga, apalagi guru mengajar pada setiap mata pelajaran. 4) Siswa dapat lebih banyak melakukan kegiatan belajar, sebab tidak hanya mendengarkan uraian guru tetapi juga aktivitas lain seperti mengamati, melakukan, mendemonstrasi, memamerkan dan lain-lain. (Arsyad, 2007: 24-25)

Jadi, dengan menggunakan media pembelajaran secara tepat dan bervariasi dapat mengatasi sifat pasif yang terjadi pada anak didik. Dalam hal ini, media pengajaran berguna untuk: menimbulkan minat belajar, memungkinkan interaksi yang lebih langsung antara anak didik dengan lingkungan, memungkinkan anak didik belajar sendirisendiri menurut kemampuan dan minat.

Gerlach dan Ely dalam Arsyad mengemukakan ada tiga ciri media yaitu sebagai berikut: 1) Ciri Fiksatif (Fixative Property), ciri ini menggambarkan kemampuan media merekam, menyimpan, melestarikan, dan merekonstruksi suatu peristiwa atau objek. Ciri ini amat penting bagi guru karena kejadiankejadian atau objek yang telah di rekam atau disimpan dengan format media yang dapat digunakan setiap saat. 2) Ciri Manipulasi (Manipulasi Property), transformasi suatu kejadian atau objek dimungkinkan karena 
media memiliki ciri manipulative. Kejadian yang memakan waktu berhari-hari dapat disajikan kepada siswa dalam waktu dua atau tiga menit dengan mengedit hasil rekaman. Kemampuan media dan ciri manipulative memerlukan perhatian sungguh-sungguh karena apabila terjadi kesalahan dalam pengaturan kembali urutan kejadian atau pemotongan bagian-bagian yang salah, maka akan terjadi pula kesalahan penafsiran yang tentu saja akan membingungkan dan bahkan menyesatkan sehingga dapat mengubah sikap siswa kearah yang tidak diinginkan.

3) Ciri Distributif (Distributive Property), Ciri ini memungkinkan suatu objek atau kejadian ditransformasikan melalui ruang, dan secara kebersamaan kejadian tersebut disajikan kepada sejumlah besar siswa dengan stimulus yang relative sama mengenai kejadian itu.

Media gambar mempunyai beberapa kelebihan yaitu sebagai berikut: 1) dapat menjelaskan masalah dalam bidang apa saja. Dan dapat digunakan untuk semua orang tanpa memandang umur, 2) dapat mengatasi keterbatasan mata. 3) lebih konkret dan lebih realistic dalam memunculkan pokok masalah, jika dibandingkan dengan bahasa verbal.

Sedangkan kelemahan-kelemahan media gambar atau foto adalah: 1) kelebihan dan penjelasan guru dapat menyebabkan timbulnya penafsiran yang beda sesuai dengan pngetahuan masing-masing aspek terhadap hal yang dijelaskan. 2) penghayatan tentang materi kurang sempurna, karena media gambar hanya menampilkan persepsi indera mata yang tidak cukup kuat untuk menggerakkan seluruh kepribadian manusia, sehingga materi yang dibahas kurang sempurna. 3) tidak meratanya penggunaan foto tersebut bagi anak-anak dan kurang efektif dalam penglihatan. Biasanya anak yang paling depan yang lebih sempurna mengamati foto tersebut, sedangkan anak yang belakang semakin kabur.

\section{METODE PENELITIAN}

Berdasarkan pendapat Arikunto (2006: 16), penelitian ini merupakan penelitian deskriptif kuantitatif dengan jenis Penelitian Tindakan Kelas (PTK) karena segala kegiatannya dilakukan di dalam kelas dan di fokuskan pada proses belajar mengajar.

Lokasi Penelitian Tindakan Kelas (PTK) ini dilakukan di SD Negeri 101768 yang berlokasikan di Tembung, Kecamatan Percut Sei Tuan dan Kabupaten Deli Serdang. Pemilihan lokasi penelitian ini di dasarkan pada pertimbangan bahwa peneliti merupakan guru tetap di sekolah tersebut, peneliti telah memahami karakteristik siswa yang akan di teliti dan kemampuan memahami tokoh dalam proklamasi kemerdekaan yang masih rendah.

Subjek penelitian dalam penelitian ini adalah siswa kelas V SD Negeri 101768 dengan jumlah siswa 25 orang yang terdiri dari 14 orang siswa laki-laki dan 11 orang siswa perempuan.

Sesuai dengan rumusan judul penelitian di atas, maka penelitian ini mengikuti prosedur Classroom Action Research (Penelitian Tindakan Kelas). Prosedur pelaksanaannya secara garis besar terdiri dari tiga tahap dalam tiap siklusnya, yaitu perencanaan, pelaksanaan, pengamatan dan siklus refleksi.

Tahap 1 yaitu tahap penyusunan rancangan atau rencana tindakan (planning). Peneliti menyusun rancangan atau rencana pelaksanaan pembelajaran. Diantara nya adalah menentukan SK dan KD, menyusun RPP atau membuat skenario pembelajaran dengan menggunakan media gambar. Membuat tes hasil belajar, menyiapkan lembar penilaian dan membuat lembar observasi.

Tahap II yaitu tahap pelaksanaan tindakan (Acting) dan pengamatan (Observing) yaitu peneliti melaksanakan proses pembelajaran sesuai dengan RPP yang telah di susun selanjutnya memberikan tes hasil belajar dimana pada saat mengerjakan tes hasil belajar, guru mengisi lembar observasi dan mengevaluasi hasil tes.

Tahap III yaitu tahap refleksi (Reflecting) yaitu guru dan kepala sekolah bersama-sama membahas hasil pembelajaran dan mengambil kesimpulan dari tindakan yang telah dilakukan.

Teknik pengumpulan data penelitian melalui (1) Observasi yang dilakukan pada tahap pengamatan. Observasi dilakukan untuk mengetahui bagaimana aktivitas belajar siswa 
pada saat pembelajaran berlangsung. (2) Wawancara dilakukan pada guru mata pelajaran IPS. Wawancara kepada guru dilakukan untuk mengetahui kesulitan yang biasa di alami siswa dalam memahami materi. Wawancara akan dihentikan apabila penelitian telah di capai. (3) Tes diberikan kepada seluruh siswa untuk memperoleh data mengenai kemampuan siswa dalam menguasai materi tokoh proklamasi kemerdekaan dan tingkat kemampuan pemahaman siswa.

Dari data hasil tes di analisis dengan menggunakan acuan tingkat kriteria ketuntasan (KKM) siswa terhadap materi. Seorang siswa dikatakan tuntas belajar apabila telah memperoleh nilai $\geq 70$ sesuai dengan KKM yang telah ditentukan sekolah.

Ketuntasan klasikal (kelas tersebut tuntas belajar) tercapai apabila seluruh siswa dalam kelas sudah mencapai $\geq 80 \%$. Untuk menghitung persentase ketuntasan klasikal digunakan rumus:

$$
\mathrm{P}=\frac{2 n}{N} X 100
$$

Keterangan:

P : Persentase ketuntasan belajar klasikal

$\Sigma \mathrm{n}$ : Jumlah siswa yang memperoleh nilai $\geq 75$

$\mathrm{N}$ : Banyaknya siswa

(Aqib,dkk, 2011:41)

\section{HASIL DAN PEMBAHASAN}

Hasil analisis data menunjukkan bahwa sebelum diterapkan media gambar siswa sangat pasif namun setelah diterapkan media gambar siswa menjadi lebih aktif. Daftar Observasi Aktivitas dan Partisipasi Siswa terangkum di bawah ini:
Daftar Observasi Aktivitas dan Partisipasi Siswa

\begin{tabular}{|l|l|l|}
\hline \multirow{2}{*}{ Aspek Yang Dinilai } & \multicolumn{2}{|l|}{ Ketercapaian } \\
\cline { 2 - 3 } & S I & S II \\
\hline $\begin{array}{l}\text { Memperhatikan penjelasan } \\
\text { guru dengan aktif }\end{array}$ & 88 & 96 \\
\hline $\begin{array}{l}\text { Mempersiapkan alat tulis } \\
\text { yang dibutuhkan untuk } \\
\text { pembelajaran }\end{array}$ & 100 & 100 \\
\hline Bertanya kepada guru menjawab & 44 & 80 \\
\hline $\begin{array}{l}\text { Siswa yang dalam } \\
\text { pertanyaan yang diajukan }\end{array}$ & 32 \\
\hline $\begin{array}{l}\text { Siswa yang aktif dari } \\
\text { mencari gambar/foto dan semberikan } \\
\text { tokoh serta membat } \\
\text { penjelasan secara singkat } \\
\text { mengenai perannya }\end{array}$ & 28 & 92 \\
\hline $\begin{array}{l}\text { Siswa mengerjakan soal } \\
\text { latihan }\end{array}$ & 60,7 & 83,4 \\
\hline Rata-Rata & 100 \\
\hline
\end{tabular}

Pada siklus I, secara keseluruhan targert yang diharapkan telah tercapai. Namun untuk bertanya kepada guru belum mencapai target. Karena itu, pada tahap berikut nya perlu dilakukan perbaikan agar siswa berani untuk mengajukan pertanyaan ketika guru selesai menjelaskan materi pelajaran.

Hasil belajar kognitif siswa menunjukkan adanya peningkatan dari Siklus I (56\%) ke Siklus II (84\%). Namun hasil belajar kognitif siklus I belum memenuhi target yang diharapkan. Karena itu perlu dilakukan perbaikan pada Siklus II. Perbaikan yang dilakukan antara lain guru lebih menekankan materi-materi yang masih kurang dipahami siswa, pembelajaran diubah dari persentasi kelas menjadi diskusi kelompok dan guru memberikan kesempatan kepada siswa untuk bertanya langsung kepada guru jika ada hal yang belum di pahami, serta media gambar yang dilakukan pada siklus I sudah dilakukan sesuai urutan. Pada siklus II dilakukan secara acak sehingga siswa berusaha memahami gambar-gambar tokoh dalam proklamasi kemerdekaan.

Berdasarkan hasil analisis dari pretest, Siklus I dan Siklus II maka yang menjadi pokok penting yang perlu di bahas. Pertama adalah 
Temuan Pertama, dengan mengamati hasil pertemuan pertama terdapat hasil belajar siswa pada pretest bahwa nilai pretest dari 25 siswa sebelum peneliti menerapkan pembelajaran dengan menggunakan media gambar hanya 5 siswa (20\%) yang tuntas. Sedangkan 20 siswa (80\%) belum tuntas. Tingkat ketuntasan klasikal hanya mencapai ketuntasan sebesar $20 \%$, hal ini menunjukkan nilai pretest siswa tergolong rendah dan siswa kelas V SD Negeri 101768 belum tuntas mempelajari mata pelajaran materi tokoh dalam proklamasi kemerdekaan.

Pada pertemuan kedua ini diketahui nilai siklus I dan siklus II. Berdasarkan nilai post test siklus I dari 25 siswa setelah menggunakan media gambar pada mata pelajaran IPS materi tokoh dalam proklamasi kemerdekaan sebanyak 14 siswa (56\%) sudah mencapai tingkat ketuntasan belajar dengan nilai 70 , sedangkan siswa yang belum tuntas berjumlah 11 siswa (44\%). Tingkat ketuntasan klasikal 56\%, hal ini menunjukkan bahwa siklus I masih tergolong kedalam katagori masih rendah karena masih ada 11 siswa lagi yang belum tuntas dalam mata pelajaran IPS materi tokoh dalam proklamasi kemerdekaan. Kesulitan yang di alami siswa adalah siswa tidak dapat memahami makna dari soal yang dituliskan dan siswa belum memahami tentang bagaimana gambar para tokoh beserta masing-masing peranannya.

Hasil temuan pada siklus II diketahui bahwa nilai post test dari 25 siswa setelah dilakukan pembelajaran dengan menggunakan media gambar pada mata pelajaran IPS materi tokoh dalam proklamasi kemerdekaan terdapat sebanyak 21 (84\%) sudah mencapai tingkat ketuntasan belajar dengan nilai di atas 70 sedangkan 4 siswa belum mencapai tingkat ketuntasan. Tingkat ketuntasan klasikal 84\% sudah mengalami peningkatan dan tergolong tinggi dengan demikian maka dapat dikatakan hasil belajar siswa SD Negeri 101768 sudah tuntas dalam mempelajari mata pelajaran tokoh dalam proklamasi kemerdekaan.

Dalam penerapan pembelajaran dengan menggunakan media gambar mengacu pada motivasi siswa untuk belajar karena ketika guru memberikan clue maka siswa berlombalomba mengangkat tangan agar maju kedepan kelas untuk menunjukkan kemampuannya. Dengan menggunakan media gambar, siswa dengan mudah mendapatkan partisipasi kelas sehingga dapat meningkatkan hasil belajar siswa dalam mata pelajaran IPS. Maka berdasarkan hasil temuan siklus I dan siklus II, pembelajaran dengan menggunakan media gambar dapat meningkatkan hasil belajar siswa. Pada temuan ini siswa berhasil memahami materi pembelajaran yang disampaikan oleh guru dengan pengalaman belajar yang menyenangkan dan berkesan yang dirasakan langsung oleh siswa.

Mencermati temuan ketiga selama proses pelaksanaannya pembelajaran dengan menggunakan media gambar, siswa terlihat sangat antusias dan semangat dalam mengikuti pembelajaran yang di sampaikan oleh guru. Walaupun pada siklus I masih terdapat kelemahan-kelemahan, kemudian di susunlah alternatif scenario pembelajaran yaitu sebelum masuk kepertemuan berikutnya, terlebih dahulu peneliti dan siswa membahas kelemahan-kelemahan yang dilakukan siswa pada saat menerima pelajaran dan pada saat menyelesaikan soal, kemudian setelah pemberian tindakan pada siklus II pemahaman siswa meningkat mereka dapat memahami dan menyerap apa yang telah di sampaikan.

Berdasarkan hasil penelitian dan analisa diperoleh kesimpulan bahwa upaya pembelajaran dengan menggunakan pembelajaran yang dipakai media gambar mempunyai peranan penting sebagai salah satu upaya untuk meningkatkan hasil belajar siswa.

\section{KESIMPULAN}

Dari hasil penelitian, maka dapat diambil kesimpulan bahwa hasil belajar siswa sebelum tindakan hanya mendapat ketuntasan belajar secara klasikal adalah 5 siswa 20\% dan 20 siswa belum tuntas $80 \%$ sehingga nilai ratarata yang di dapat hanya sebesar 51,2\%. Media gambar dapat meningkatkan hasil belajar siswa materi tokoh dalam proklamasi kemerdekaan. Hal ini dapat dilihat dalam pelaksanaan siklus I dan siklus II. Pada siklus I persentase rata-rata 
$67,6 \%$ yang kemudian meningkat pada siklus II menjadi 84\%. Berdasarkan hasil observasi respon belajar siswa dengan menggunakan media gambar juga sangat baik, para siswa terlihat lebih aktif serta termotivasi dalam melaksanakan pembelajaran yang sedang berlangsung. Hal ini terlihat siswa yang fokus terhadap materi dan mendengarkan aba-aba (clue) yang diberikan oleh guru selama pembelajaran berlangsung.

\section{DAFTAR PUSTAKA}

Arsyad, Azhar. 2002. Media Pembelajaran. Jakarta: PT. Raja Grafindo Persada.

Arsyad, Azhar. 2007. Media Pembelajaran. Jakarta: PT. Raja Grafindo Persada.
Asnawir. 2002. Media Pembelajaran. Jakarta: Ciputat Pers.

Aqib, Zainal. 2009. Penelitian Tindakan Kelas. Bandung: CV. YRAMA WIDYA.

Moleong, Lexy J. Metodologi Penelitian Kualitatif. Bandung: PT. Remaja Rosdakarya.

Ruslan, Rosady. 2008. Metode Penelitian. Jakarta: PT. Raja Grafindo Persada.

Sadiman, Arief S. 2007. Media Pendidikan, Pengertian, Pengembangan dan Pemanfaatannya. Jakarta: PT. Raja Grafindo Persada.

Sudjana, Nana. 2008. Penilaian Hasil Proses Belajar Mengajar. Bandung: Remaja Rosdakarya.

Syamsiah, Siti. 2008. Ilmu Pengetahuan Sosial. Departemen Pendidikan Nasional.

Syah, Muhibbin. 2003. Psikologi Suatu Pendekatan Baru. Bandung: Remaja Rosdakarya.

Wijaysa, Candra. 2013. Penelitian Tindakan Kelas. Bandung: Citapustaka Media Perintis. 